\title{
Wojciech Górski
}

\section{Niezgodność charakterów stron a incapacitas assumendi (kan. 1095, n. $3 \mathrm{KPK})$ na przykładzie wyroku Roty Rzymskiej c. Burke z 18 lipca 1997 roku}

Ius Matrimoniale 13 (19), 179-192

2008

Artykuł został opracowany do udostępnienia w internecie przez Muzeum Historii Polski w ramach prac podejmowanych na rzecz zapewnienia otwartego, powszechnego i trwałego dostępu do polskiego dorobku naukowego i kulturalnego. Artykuł jest umieszczony w kolekcji cyfrowej bazhum.muzhp.pl, gromadzącej zawartość polskich czasopism humanistycznych i społecznych.

Tekst jest udostępniony do wykorzystania w ramach dozwolonego użytku. 

$\begin{array}{lllllllllllllllllll}O & R & Z & E & C & Z & N & I & C & T & W & O & & S & A & D & O & W & E\end{array}$
Ius Matrimoniale
13 (19) 2008

\author{
Ks. Wojciech Górski
}

\title{
Niezgodność charakterów stron a incapacitas assumendi (kan. 1095, n. 3 KPK) na przykładzie wyroku Roty Rzymskiej c. Burke z 18 lipca 1997 roku
}

\section{I}

Wynikająca $z$ prawa naturalnego, a usankcjonowana w kan. 1095 , n. 3 KPK z 1983 roku jedna z trzech form niezdolności konsensualnej do zawarcia małżeństwa, polegająca na niezdolności do podjęcia z przyczyn natury psychicznej - istotnych obowiązków małżenskich, stanowi najczęściej występujący na forum sądowym tytuł nieważności małżeństwa.

Niezdolność do podjęcia istotnych obowiązków małżeńskich dotyka osób, które, choć posiadają wystarczające używanie rozumu i nie przejawiają poważnego braku rozeznania oceniającego co do tychże obowiązów, to jednak $z$ uwagi na swój patologiczny stan psychiczny są niezdolni do ich podjeccia, a tym samym i wypelnienia, nawet gdy chca je świadomie, dobrowolnie i z należytą ich ocena podjąć $c^{1}$. Tak określona incapacitas assumendi tylko wówczas powoduje nieważność małżeństwa, gdy występuje w momencie zawierania tego zwiazku.

W tekście kan. 1095, n. 3 KPK należy dostrzec trzy następujące elementy składające się na treść normy prawnej: 1) niemożliwość podjęcia (sytuacja uniezdalniająca podmiot); 2) z przyczyn natury psychicznej (źródło niezdolności); 3) istotnych obowiązków małżeńskich (przedmiot określający niezdolność w sferze prawnej, wynikający z kan. $1055 \S 1 \mathrm{KPK}$ ).

Tak określona treść normy prawnej nie zawsze bywa właściwie

\footnotetext{
1 ,Quapropter; incapacitas de qua heic agimus, videtur eas afficere personas, etsi fruuntur sufficienti rationis usu neque gravier deficiunt iudicii discretione, tamen ob suam psychicam condicionem pathologicam ita habendam, impares exstant ad essentiales matrimonii obligationes adsumendas seu perficiendas, quidem forte scienter, libere et debita aestimatione volitas". Dec. c. Pompedda z 15. 07. 1994 r. RRDec. 86(1994), s. 395.
} 
rozumiana, między innymi gdy chodzi o pierwszy ze wskazanych elementów: niejednokrotnie pod pojęcie niemożliwości podjęcia istotnych obowiązków małżeńskich usiłuje się podciagnąć szczególną trudność w tym zakresie.

\section{II}

Instruującym przykładem konieczności zdecydowanego odróżniania prawdziwej niezdolności (niemożliwości) od zwykłej trudności w podjęciu istotnych obowiązków małżeńskich może być wyrok Roty Rzymskiej c. Cormac Burke z 18 lipca 1997 roku w sprawie Singaporen. Nullitatis matrimonii ${ }^{2}$. Orzeczenie to (non constare de nullitate) zapadło w III instancji, potwierdzając podobne rozstrzygnięcie poprzedniego turnusu rotalnego (c. Emilio Clagiovanni), jako trybunału II instancji. Natomiast wyrokiem I instancji (Trybunału Kościelnego w Singapurze) stwierdzono nieważność małżeństwa $\mathrm{z}$ tytułu niezdolności stron do wyrażenia konsensu małżeńskiego z powodu radykalnej różnicy (niekompatybilności) charakterów (radical incompatibility of character). Należy dodać, że mężczyzna wniósł sprawę z tytułu niezdolności pozwanej do nawiązania wspólnoty małżeńskiej z powodu zaburzeń charakteru i temperamentu, a dubium postawione przy zawiązaniu sporu dotyczyło poważnego braku rozeznania oceniającego po stronie tejże pozwanej. Jednak na wniosek patrona powoda trybunał zmienił tę formułę na wyżej wskazaną ${ }^{3}$.

Orzeczenie c. Burke, stanowiące - w części in iure - obszerny wywód wybitnego audytora rotalnego na temat różnicy pomiędzy niezdolnością do podjęcia istotnych obowiązków małżeńskich a trudnością w ich podjęciu, obejmuje szereg istotnych ustaleń przyjętych w judykaturze rotalnej, podobnie zresztą jak i w doktrynie kanonicznego prawa małżeńskiego. Zostały one pomieszczone w obrębie dwóch podstawowych wątków wspomnianej części wyroku.

$W$ pierwszym $z$ owych watków redaktor orzeczenia rotalnego, nawiązując do wyroku sądu pierwszej instancji, porusza kwestię relewantności prawnej psychologicznego pojęcia niekompatybilności charakterów. Już na wstępie podkreśla, że tę ostatnią Rota Rzymska konsekwentnie odrzuca jako tytuł kanoniczny uprawniony do stwier-

\footnotetext{
${ }^{2}$ Dec. c. Burke z 18. 07. 1997 r., RRDec. 89(1997), s. 609-619 (pozostalymi audytorami byli: A. Stankiewicz i I. M. Serrano Ruiz).

${ }^{3}$ Zob. tamże, s. 609-610.
} 
dzenia nieważności konsensu małżeńskiego. Przywołując wyrok II instancji w omawianej sprawie (z 5 marca 1991 roku) ${ }^{4}$ zauważa, że tytuł ten nieznany jest ani KPK, ani doktrynie czy orzecznictwu, źródłem więc niezdolności do powzięcia konsensu małżeńskiego nie może być różnica czy też niekompatybilność charakterów, co ma miejsce $\mathrm{w}$ świeckim porządku prawnym w odniesieniu do rozwodu ${ }^{5}$.

Różnica charakteru mężczyzny i kobiety, stwierdza następnie ponens odwołując się do wyroku rotalnego c. Di Felice z 12 listopada $1977 \mathrm{roku}^{6}$, nie pozbawia zdolności przekazania i przyjęcia praw i obowiązków małżeńskich. W świetle bowiem antropologii chrześcijańskiej, biorąc pod uwage fundamentalny nakaz kochania wszystkich bez wyjątku, należy wątpić, czy w ogóle można mówić o absolutnej niekompatybilności. Sami psychologowie podnoszą niekiedy watpliwości co do waloru pojęcia niekompatybilności podstawowej, inaczej istotnej. Dowodem tego może być wypowiedź psychiatry, jaka znalazła się w wyroku rotalnym c. Road z 14 kwietnia 1975 roku$^{7}$, w oparciu o którą stwierdzono, że niekompatybilność istotna nie unieważnia małżeństwa ${ }^{8}$.

Zatrzymując się nad różnorodnością wychowania i/albo doświadczenia kulturowego, Burke zauważa, że może ona spowodować znaczne różnice w tym, czego dwie osoby oczekują od życia małżeńskiego, albo jak jedna i druga pojmuje sposób prowadzenia go. Co więcej, stwierdza, różnica charakterów, jak to głosi wyrok drugiej instancji ${ }^{9}$, będąca dla każdego człowieka czymś naturalnym i osobistym, może osiągnąć tak ekstremalne rozmiary, że ma miejsce niekompatybilność co do wartości, sposobów interpretowania rzeczywistości, formy odnoszenia się w relacjach międzyosobowych, co najczęściej czyni te relacje czymś trudniejszym, lecz nie czyni ich czymś niemożliwym.

Nie bez znaczenia jest odwołanie się w wyroku do przemówienia papieża Jana Pawła II do Roty Rzymskiej z 5 lutego 1987 roku $^{10}$. W przytoczonym fragmencie tej doniosłej dla doktryny i praktyki sądowniczej alokucji Ojciec święty stwierdza, że dla kanonisty powin-

\footnotetext{
${ }^{4}$ Dec. c. Clagiovanni z 05. 03. 1991 r., RRDec. 83(1991), s. 138 i 143.

${ }^{5}$ Dec. c. Burke, jw., s. 610.

${ }^{6}$ Dec. c. Di Felice z 12. 11. 1977 r., RRDec. 69(1977), s. 453 nn.

${ }^{7}$ Dec. c. Road z 14. 04. 1975 r., RRDec. 67(1975), s. 258 nn.

${ }^{8}$ Dec. c. Burke, jw., s. 610.

${ }^{9}$ Dec. c. Coagiovanni, jw., s. 139.

${ }^{10}$ Ioannes Paulus II, Allocutio diei 5 februarii 1987, AAS 79(1987), s. 1457.
} 
na być jasna zasada, iż jedynie niezdolność, a nie trudność [podkreślenia $\mathrm{w}$ tekście] do powzięcia konsensu i do zrealizowania prawdziwej wspólnoty życia i miłości, czyni małżeństwo nieważnym. Upadek jedności małżeńskiej nie stanowi więc nigdy dowodu na rzecz niezdolności kontrahentów, którzy mogli zaniedbać lub niewłaściwie używać środków zarówno naturalnych, jak i nadprzyrodzonych będących do ich dyspozycji, lub nie akceptować niezbędnych ograniczeń i ciężarów życia małżeńskiego wskutek czy to blokad w sferze podświadomości, czy nieznacznych patologii, które nie naruszają istotnej wolności ludzkiej, czy wreszcie w rezultacie braków porządku moralnego ${ }^{11}$.

Jest rzeczą właściwa, czytamy następnie w wyroku, że mąż i żona stają się na równi uczestnikami wszystkich decyzji dotyczących życia małżeńskiego i rodzinnego. Może więc ktoś utrzymywać, że wszystkie tego rodzaju decyzje powinny być owocem dwóch woli i umysłów, które łączą się w jednej harmonijnej duszy, a to stanowi bardziej ideał niż rzeczywistość. Tymczasem może się zdarzyć, że dwie osoby, którym zupełnie obojętne jest, kto decyduje w danej sprawie, dobrze się czują się w swoich relacjach międzyosobowych (choć najprawdopodobniej troska o rodzinę, którą zakładaja, nie będzie wystarczająca). Jedność małżeńska pomiędzy osoba, która byłaby zdecydowana i przyzwyczajona do działania decyzyjnego, a druga, opieszałą i bierna, może układać się dobrze w aspekcie czy to międzyosobowym czy rodzinnym. Przeciwnie, związek między dwiema osobami decyzyjnymi i nieskłonnymi do ustępstw z pewnością naznaczony będzie licznymi nieporozumieniami we wzajemnych relacjach międzyosobowych. Jednocześnie, w każdym $z$ tego rodzaju przypadków zawsze jest możliwe, iż życie małżeńskie zmieni się na gorsze z przyczyn niezwiazanych z charakterami małżonków, takich jak nieszczęśliwy wypadek, przedłużająca się choroba i ułomność, trudności ekonomiczne itd. Jakkolwiek by nie było, stwierdza ponens, okazuje się, że odniesienia osobowe lub międzyosobowe, jak i te wspomniane, nie stanowią żadnej podstawy dla figury prawnej niezdolności konsensualnej z kan. $1095 \mathrm{KPK}^{12}$.

W nawiązaniu do orzeczenia c. Colagiovanni z 2 lutego 1988 roku $^{13}$, redaktor omawianego wyroku stwierdza następnie, że upadek wspólnoty życia i miłości nade wszystko może nastąpić $z$ powodu konfliktowej osobowości, która była ,ukryta” przed zawarciem mał-

\footnotetext{
${ }^{11}$ Dec. c. Burke, jw., s. 611.

${ }_{12}$ Tamże.

${ }^{13}$ Dec. c. Colagiovanni z 02. 02. 1988 r., RRDec. 80(1988), s. 48.
} 
żeństwa, a następnie ujawniła się. Lecz zwykła różnica charakteru, wychowania, projektowania własnego życia na przyszłość nie stanowi przeszkody dla istotnych obowiązków małżeńskich ${ }^{14}$.

Drugi wątek uzasadnienia wyroku in iure dotyczy pojęcia niemożliwości moralnej, prawnie aplikowanego do kan. 1095, n. 3 KPK. Odnosząc się na wstępie do orzeczenia trybunału pierwszej instancji, ponens zauważa, że mówi się tam o niekompatybilności charakterów stron oraz o pewnym osobowym nieuporzadkowaniu czy niedojrzałości emocjonalnej. Gdy weźmie się pod uwage przytoczone wcześniej ustalenia $\mathrm{w}$ przedmiocie niekompatybilności, nadmienia Burke, to owe stwierdzenia wyroku trybunału w Singapurze nasuwaja pewne uwagi.

Tak więc zdaniem ponensa turnusu rotalnego, najpierw nie należy przyjmować nieważności małżeństwa z powodu ,jakiegoś rodzaj osobowego nieuporządkowania" (some kind of personal disorder) albo „niedojrzałości emocjonalnej” (emotional immaturity), bliżej nieokreślonych. Konieczne jest, by z akt sprawy mogła wynikać pewność moralna co do jakiejś poważnej anomalii psychicznej, $\mathrm{i}$ to istniejącej w momencie zawierania związku. Jasna jest tutaj norma, która powinna się kierować jurysprudencja, przypomniana przez papieża Jana Pawła II, wiążaca wszystkie trybunały kościelne. Ojciec święty, w swoich alokucjach do Roty Rzymskiej z 1987 i 1988 roku stwierdził, że prawdziwa niezdolność jest możliwa jedynie w przypadku poważnego rodzaju anomalii, która, jakkolwiek by się chciało ją zdefiniować, powinna naruszać w sposób istotny zdolność rozumienia $\mathrm{i} /$ lub chcenia kontrahenta ${ }^{15}$, oraz że jedynie formy poważniejszej psychopatologii są w stanie naruszyć istotną wolność osoby ${ }^{16}$.

Niemal wszystkie rozpadnięcia się małżeństw, stwierdza się w wyroku, spowodowane sa trudnościami lub przeszkodami w relacji międzyosobowej pomiędzy małżonkami, których jedna czy druga strona nie akceptuje lub nie pokonuje. Niepowodzenie w przezwyciężaniu owych trudności lub przeszkód nigdy nie stanowi samo w sobie dowodu dla stwierdzenia niezdolności do ich pokonania lub poddania się im. Tego pokonywania przeciwności komuś może zabraknąć z powodu niedbałości lub lenistwa, lecz to nie oznacza, że zabrakło mu tego z powodu niezdolności ${ }^{17}$.

\footnotetext{
${ }^{14}$ Dec. c. Burke, jw., s. 611.

${ }^{15}$ Ioannes Paulus II, Allocutio diei 5 februarii 1987, AAS 79(1987), s. 1457.

${ }^{16}$ Ioannes Paulus II, Allocutio diei 25 ianuarii 1988, AAS 80(1988), s. 1182.

${ }^{17}$ Dec.c. Burke, jw., s. 612.
} 
Nieszczęśliwy final małżeństwa, kontynuuje redaktor wyroku, jest zwyklą sprawą faktu, co można latwo udowodnić. Tymczasem prawdziwa i konstytutywna niezdolność do podjęcia istotnych obowiązków małżeńskich, do których należy między innym powinność zachowania życia wspólnego, czy akceptowania nierozerwalności związku, jest figurą prawną kanoniczna, która wymaga ścisłego udowodnienia dla prawomocnego stwierdzenia $w$ danym przypadku nieważności małżeństwa ${ }^{18}$.

Przechodząc do relacji między niezdolnością kanoniczną a niemożliwością moralna, Burke odwołuje się najpierw do oczywistej zasady prawa rzymskiego: Impossibilium nulla est obligatio ${ }^{19}$, przyjmowanej następnie w chrześcijańskiej doktrynie i praktyce, tak moralnej, jak i prawnej, znana między innymi św. Tomaszowi z Akwinu ${ }^{20}$ i św. Alfonsowi ${ }^{21}$. Bardziej współczesna teologia zasadę tę wzbogaciła, wyróżniając niemożliwość fizyczną i moralną.

Niemożliwość fizyczna, wyjaśnia się w orzeczeniu, ma charakter absolutny i wymawia od zachowania jakiegokolwiek prawa, czy pochodzenia naturalnego czy tylko pozytywnego (nawet Bożego). Prawo wówczas nie obowiązuje, ponieważ jego zachowanie jest całkowicie niemożliwe. Może to mieć miejsce np. w przypadku ciężko chorej osoby, która nie może uczestniczyć we Mszy św. niedzielnej.

Gdy chodzi natomiast o niemożliwość moralną, ta żadną miarą nie stanowi prawdziwej niemożliwości [podkr. w tekście]. Jest ona raczej zasada, według której ktoś nie jest związany prawami pozytywnymi [podkr. w tekście], gdy ich spełnienie wymaga wysiłków wprost nadzwyczajnych, a uważa się, iż nie taki był mens legislatoris. Tego rodzaju sytuacja może zaistnieć między innymi wówczas, gdy osoba zdrowa, której samochód zepsuł się, i $z$ tego powodu nie może udać się na Mszę św. niedzielną do świątyni bardzo odległej. Zapewne mogłaby to uczynić idąc w obydwie strony np. osiem godzin; jednak obowiązek wynikający z prawa pozytywnego nie uważa się za taki, którego wypełnienie wymaga podjęcia ekstremalnych wysiłków. Kto więc znajduje się $w$ takich okolicznościach, uważany jest rozumnie za pozostającego w sytuacji moralnej [podkr. w tekście] niemożliwości spełnienia obowiązku wynikającego z prawa pozytywnego ${ }^{22}$.

\footnotetext{
${ }_{18}$ Tamże.

19 D. 50.17 .185 , lib. 8 (Celsus).

20 S. Thoma, Summa theologiae, Suppl., q. 58, art. 1.

21 S. Alphonsus, Teologia moralis, Parigi 1928, lib. I, n. 176.

22 Dec. c. Burke, jw., s. 612-613.
} 
Z kolei padają $\mathrm{w}$ orzeczeniu doniosłe stwierdzenia, iż $\mathrm{w}$ przeciwieństwie do niemożliwości fizycznej, niemożliwość moralna nigdy nie wymawia od wypełnienia prawa naturalnego, ponieważ prawo to obowiązuje także [podkreślenia w tekście] przy poważnej niedogodności, i że obowiązek prawa naturalnego nie ustępuje przed żadną szkodą lub niedogodnością ${ }^{23}$. Lapidarnie ponens konkluduje, że niemożliwość fizyczna, czyli absolutna zwalnia od wszelkich praw, natomiast niemożliwość moralna wymawia jedynie od prawa ludzkiego. Formułując te stwierdzenia, Burke odwołuje się do kilku podręczników teologii moralnej ${ }^{24}$.

Podnosząc następnie kwestię aplikacji przytoczonych wyżej zasad do kan. 1095, n. 3 KPK, redaktor orzeczenia rotalnego stawia bardzo zasadnicze pytanie: czy istotne [podkr. w tekście] obowiązki małżeńskie pochodza z prawa Bożego naturalnego, czy też tylko z prawa pozytywnego (Bożego lub kościelnego). Na pytanie to daje od razu zdecydowaną odpowiedź, iż nie można watpić, że pochodzą one z prawa Bożego naturalnego. Jeśli bowiem jakiś obowiązek małżeński jest rzeczywiście istotny i konstytutywny, to znaczy, że jego obowiązywalność nie pochodzi z prawa pozytywnego, lecz niewatpliwie $z$ prawa Bożego naturalnego ${ }^{25}$.

Istotne obowiązki małżeńskie wiążą zatem również, zauważa ponens, gdy ich spełnianie wiąże się z poważną niedogodnością (cum gravi incommodo). Prawdziwości tej tezy dowodza argumenty pochodzace z przesłanki naturalnej, bez konieczności odwoływania się do jakiegokolwiek wyższego źródła. W każdej przecież umowie o charakterze uroczystym, zawieranej czy to między państwami czy między osobami, domniemywa się, iż pakty wzajemnej wierności należy zachowywać, niezależnie od poważnych trudności jednej czy obydwu stron. W obszarze ludzkich relacji międzyosobowych, małżeństwo, jako pakt, zajmuje naczelne miejsce co do znaczenia i godności. Niewiele zostałoby z tej naturalnej godności, jeśli prawdą byłoby, że jego istotne obowiązki ustają - lub dokładniej mówiąc, nie zostały nigdy ważnie pod-

\footnotetext{
${ }^{23}$,Aliter ac impossibilitas physica, ista impossibilitas moralis numquam excusat ab impletione legum naturalium; quoniam hae leges obligant etiam cum gravi incommodo. Obligatio legis naturalis nulli damno vel incommodo cedit". Tamże, s. 613.

${ }^{24}$ Są to podręczniki następujących autorów: A. Sweens, A. Lehmkuhl, D.M Prümer, J. Aertnys-Damen,

M. M. Zalba i A. Günthör.

${ }^{25}$ „Si aliqua obligatio coniugals est revera essentialis ac constitutionalis, insequitur quod eius obligatorietas non a lege positiva, sed a lege divino-naturali, sine dubio derivat". Dec. c. Burke, jw., s. 613.
} 
jęte - w momencie, w którym ich zachowanie zaczyna nieść ze sobą jakąś istotną niedogodność dla jednego lub obojga małżonków ${ }^{26}$.

W kwestii możliwości (czy też nie) aplikacji normy czy miary „poważnej niedogodności”, stosowanej na gruncie teologii moralnej, do kanonicznego rozwiązywania trudnych przypadków, o których w kan. 1095, n. 3, w wyroku podkreśla się, iż jest to niemożliwe. Przywołując opinię A. Stankiewicza, według której stosowanie pojęcia niemożliwości moralnej $\mathrm{w}$ dziedzinie niezdolności naturalnej (psychicznej) jest niewłaściwe ${ }^{27}$, ponens zwraca uwagę, że wymieniony kanon nie uwzględnia bynajmniej przypadku niemożliwości moralnej (hipoteza ta niesie ze sobą konotacje relatywności), lecz przypadek niemożliwości in se rzeczywistej [podkr. w tekście].

Następnie Burke zauważa, że jest czymś bardzo właściwym, iż orzecznictwo pozostaje przy własnych analizach, tak by nie mieszać różnych nauk, które, choć zajmują się tą samą materialnie rzeczywistościa, to jednak różnią się przedmiotem, metodami, celem i racja wewnętrzna. Słusznie zwrócił na to uwagę turnus rotalny w wyroku c. Pompedda z 1 lutego $1982 \mathrm{roku}^{28}$ postulując zachowanie „czystości metodologicznej", tak aby odnośne terminy i pojęcia stosowane w różnych naukach nie były zamiennie przejmowane $z$ jednej do drugiej ${ }^{29}$.

Są tacy, stwierdza się następnie w wyroku c. Burke, którzy sugeruja używanie - jako adekwatnego - terminu „niemoźliwość psychiczna", co skłania do zwrócenia uwagi na radykalne przyczyny niezdolności, które powinny odznaczać się określona ciężkościa, powodująca prawdziwą incapacitas, nie zaś tylko prawdziwą „trudność moralną". W tym miejscu odwołano się do wyroku rotalnego c. Ragni z 23 marca 1993 roku $^{30}$, w którym podkreśla się, że kan. 1095, n. 3 odnosi się i dotyczy „niemożliwości prawnej” podjęcia istotnych obowiązków małżeńskich. Właśnie niemożliwość prawna właściwie wskazuje, iż prawo w żaden sposób nie rodzi niezdolności (wówczas obowiązki, o których mowa, nabierałyby mocy z nakazu czysto pozytywnego, byłoby więc usprawiedliwione odniesienie się do moralnej niemożliwości), lecz ją jedynie deklaruje, jako rzeczywistość prawa

\footnotetext{
${ }^{26}$ Tamże.

${ }^{27}$ Ponens powołuje się na pracę A. Stankiewicza: L'incapacità di assumere e compiere gli obblighi coniugali essenziali, złożoną do druku i wydania w 1998 roku. Zob. tamże, s. 614 .

${ }_{28}$ Dec. c. Pompedda z 01. 02. 1982 r., RRDec. 74(1982), s. 88.

${ }^{29}$ Dec. c. Burke, jw., s. 614.

${ }^{30}$ Dec. c. Ragni z 23. 03. 1993 r., RRDec. 85(1993), s. 172.
} 
Niezgodność charakterów stron a incapacitas assumendi (kan. 1095, n. 3 KPK) na przykładzie wyroku Roty Rzymskiej c. Burke z 18 lipca 1997 roku

naturalnego. W sferze zaś prawa naturalnego „niemożliwość prawna” oznacza właśnie realnq [podkreślenia w tekście] niemożliwość dokonania aktu, który byłby prawnie skuteczny.

W nawiązaniu do pracy A. Stankiewicza ${ }^{31}$ ponens uznaje za w pełni uzasadnioną opinię, w myśl której, mówiąc o istotnych obowiązkach małżeńskich z prawa Bożego - pozytywnego i naturalnego - powinno się raczej mówić o niemożliwości naturalnej o charakterze psychicznym [podkr. moje - W.G.] albo po prostu o niemożliwości psychicznej wypełnienia owych obowiązków, a nie o niemożliwości moralnej.

Kodeks stanowi, czytamy następnie w orzeczeniu, iż małżonkowie powinni zachować wspólnotę życia, chyba że wymawia ich od tego zgodna $z$ prawem przyczyna (kan. $1151 \mathrm{KPK}$ ). Ostatnie słowa kanonu jasno wskazuja, że obowiązek małżeński życia wspólnego nie ma charakteru absolutnego. Gdy chodzi o obowiązek wynikajacy z prawa pozytywnego, to jego niezachowanie aktualne (zerwanie życia wspólnego) jest godziwe, gdy np. życie to staje się zbyt trudne dla jednej strony lub wydaje się dla niej albo dla obydwu stron nie do zniesienia. Kan. 1153 KPK uznaje za prawowita przyczynę odejścia strony sytuację, w której współmałżonek czyni życie wspólne zbyt trudnym ${ }^{32}$.

Doniosłe wydaje się stwierdzenie zawarte w wyroku, iż nie brak orzeczeń rotalnych, w których utrzymuje się, że ważność zgody małżeńskiej wymaga zdolności do podjęcia relacji międzyosobowej, którą można by przynajmniej tolerować ${ }^{33}$. W świetle wyroku Roty Rzymskiej c. Serrano Ruiz z 1 czerwca 1990 roku $^{34}$ oznacza to, że terminy: „nie do tolerowania” (intolerabilis) oraz „nieważny” (nullus) stają się jakby równoznacznymi, a tym samym uprawniony byłby zwrot: „nieważne lub nie do tolerowania małżeństwo”. Tego rodzaju stwierdzenie, zauważa Burke, wykracza poza to, co wynika z kan. $1153 \S 1 \mathrm{KPK}$. Kanon ten jasno wskazuje, że wspólnota nie do tolerowania (vitam communem nimis duram reddat) stanowi kryterium dopuszczające separację [podkr. podr. tekście] małżonków, żadną zaś miarą nie jest kryterium pozwalającym na stwierdzenie nieważności węzła małżeńskiego ${ }^{35}$.

\footnotetext{
${ }^{31}$ A. Stankiewicz, L'incapacità, jw., s. 18.

${ }^{32}$ Dec. c. Burke, jw., s. 614.

${ }^{33}$ Powolano tutaj wyrok c. Faltin z 28. 10. 1988 r. RRDec. 80(1988), s. 580.

${ }^{34}$ Dec. c. Serrano Ruiz z 01. 06. 1990 r., RRDec. 82(1990), s. 453 nn.

35 „Hoc praetermittit id quod ex can. $1153 \S 1$ eruitur. Canon in claram lucem point consortii intolerabilitatem ("vitam commnem nims duram") praebere criterion ad separationem coniugum permittendam, minime ad invaliditatem vinculi inter eos declarandam". Dec. c. Burke, jw., s. 615.
} 
Jądrem poruszanej tu kwestii, zaznacza ponens, jest zdolność do powzięcia konsensu dotyczącego stworzenia węzła małżeńskiego. Od chwili, w której ważnie on powstaje, zawsze może być zachowany. Ani w znaczeniu prawnym ani w znaczeniu potocznym nie do przyjęcia jest niemożliwość akceptowania natury nierozerwalnej węzła małżeńskiego. Małżonkowie zawsze mogą lękać się węzła, chociażby jego normalna konsekwencja - prawo i obowiązek życia wspólnego - stopniowo stawała się „niemożliwa" dla jednej czy obydwu stron; owszem, chociażby nawet separacja de facto stała się usprawiedliwiona i rozsądna $z$ punktu widzenia duszpasterskiego ${ }^{36}$.

Przytoczone w części in iure orzeczenia zasady znalazły swoją aplikację w jego części in facto. Zarówno w oparciu o zeznania stron, jak i zeznania świadków turnus uznał, że choć strony okazały się w jakiejś mierze niedojrzałe, to stopień tej niedojrzałości bynajmniej nie miał znamion patologii. Jak to stwierdzono w wyroku drugiej instancji, pomiędzy stronami zachodziła różnica charakterów, wynikająca $z$ odmiennej struktury psycho-fizycznej oraz różnorodności kulturowej, co powodowało czeste spory i nieporozumienia. Nie bez znaczenia dla rozpadnięcia się związku były także naganne obyczaje powoda, godzące w obowiązki małżeńskie, szczególnie wierności i miłości. Przyczyną upadku wspólnoty małżeńskiej nie była natomiast jego niezdolność do podjęcia istotnych obowiązków małżeńskich. Próba zaś uzasadnienia tezy powoda o incapacits assumendi pozwanej ograniczyła się jedynie do stwierdzenia, że raz nie wypełniła ona obowiązku małżeńskiego uznanego przez niego za istotny ${ }^{37}$.

Szczególnej wagi nabiera konstatacja ponensa, iż zdolność do unikania w każdym momencie sporów we wspólnocie małżeńskiej, jakkolwiek bardzo pożądana w aspekcie moralnym, nie może być wskazywana jako element konstytutywny zdolności konsensualnej w rozumieniu kan. $1095^{38}$.

Należy dodać, że turnus rotalny, odwołując się do kan. $1680 \mathrm{KPK}$, uznał za zbędne powoływanie biegłego w sprawie ${ }^{39}$.

W zakończeniu orzeczenia (przed jego częścią dyspozycyjna) stwierdzono, że można rozumnie przyjąc, iż decyzja stron na zawar-

${ }^{36}$ Tamże.

${ }^{37}$ Zob. tamże, s. 615-617.

38 „Vix est necessarium addere quod habilitas ad rixas in omni momento evitandas in convictu coniugali, quantumvis desiderabilis sub aspectu morali, minime proponi potes sicut constitutivum elementum capacitatis consensualis sub terminis can. 1095". Tamże, s. 617.

${ }^{39}$ Tamże, s. 618. 
Niezgodność charakterów stron a incapacitas assumendi (kan. 1095, n. 3 KPK) na przykładzie wyroku Roty Rzymskiej c. Burke z 18 lipca 1997 roku

cie małżeństwa była nieroztropna. Związki bowiem zawierane pomiędzy osobami wywodzacymi się z różnych narodów lub kultur, coraz częściej spotykane, jakkolwiek w przeważającej mierze okazują się udane, to jednak jest to rezultatem wysiłków małżonków skierowanych ku pokonywaniu lub akceptowaniu owych różnic. Tego rodzaju działań zabrakło natomiast u stron $w$ referowanej sprawie $\mathrm{e}^{40}$.

\section{III}

Zaprezentowany wyrok Roty Rzymskiej c. Burke stanowi jeden z przykładów właściwego rozumienia niezdolności do podjęcia istotnych obowiązków małżeńskich w rozumieniu kan. 1095, n. 3 KPK.

Przyjęcie do instrukcji przez trybunał pierwszej instancji sprawy z tytułu niezdolności stron do wyrażenia konsensu małżeńskiego z powodu radykalnej różnicy (niekompatybilności) charakterów, a następnie stwierdzenie $\mathrm{z}$ tego powodu nieważności małżeństwa, było zwykłym nieporozumieniem, czemu dały wyraz trybunały kolejnych instancji: drugiej i trzeciej.

W obszernym wywodzie ponensa zawartym o orzeczeniu trybunału trzeciej instancji zdecydowanie zdezawuowano pogląd, w myśl którego niezgodność charakterów kontrahentów, powodująca nawet poważne trudności w wypełnianiu istotnych obowiąków malżeńskich, przesądza o niezdolności do ich podjęcia, a tym samym i wypełnienia. Szersze naświetlenie i wyjaśnienie natury owych trudności, szczególnie w aspekcie ich relacji do natury zdolności/niezdolności konsensualnej, pozwoliło nie tylko wykazać bezzasadność takiego zapatrywania, lecz także pełniej ukazać, czym jest w swej istocie incapacitas assumendi.

Odwołując się do szeregu rozstrzygnięć Roty Rzymskiej, ponens jednoznacznie wykazal, iż w orzecznictwie tego trybunału nie może znaleźć uznania głoszona tu ówdzie teza o relewantności prawnej tytułu nieważności w postaci niekompatybilności charakterów (pojęcie psychologiczne). Na zwrócenie uwagi zasługuje stwierdzenie, iż w świetle podstawowego nakazu - obowiązującego chrześcijan kochania bezwzględnie wszystkich, należy watpić, czy w ogóle można mówić o absolutnej niekompatybilności. Znaczące jest także odwołanie się tutaj do nauk psychologicznych, na gruncie których podnosi

${ }^{40}$ Tamże, s. 619. 
się niekiedy watpliwości co do waloru pojęcia niekompatybilności podstawowej. Bardzo trafne wydaje się poza tym przywołanie fragmentu alokucji papieża Jana Pawła II do Roty Rzymskiej z 5 lutego 1987 roku, w którym akcentuje się zasadę, w myśl której wyłącznie niezdolność do powzięcia konsensu i do urzeczywistnienia wspólnoty małżeńskiej, nie zaś trudność w tym zakresie, czyni małżeństwo nieważnym. Dobitnie zabrzmiało również w wyroku stwierdzenie Ojca świętego, będace konsekwencją owej zasady, że nieszczęśliwy finał wspólnoty małżonków nie stanowi nigdy dowodu na rzecz incapacitas assumendi.

Czymś bardzo instruującym w orzeczeniu c. Burke zdaje się być i to, co dotyczy pojęcia niemożliwości moralnej, odniesionego do kan. 1095, n. 3 KPK. Zdaniem ponensa, niemożliwość moralna nie stanowi nigdy prawdziwej niemożliwości, i w przeciwieństwie do niemożliwości fizycznej, nigdy więc nie wymawia od wypełnienia prawa naturalnego, a istotne obowiązki małżeńskie pochodzą właśnie $z$ prawa naturalnego. Obowiązki te wiążą zatem również wówczas, gdy ich spełnianie łączy się z poważną trudnością.

W zaprezentowanym orzeczeniu znaczace jest ponadto niebudzące watpliwości odrzucenie wszelkich prób utożsamiania znaczenia terminów intolerabilis oraz nullus w odniesieniu do matżeństwa, wspólnota bowiem, w której życie staje się zbyt trudne, może uciec się jedynie do separacji, nie może natomiast zostać uznana za zawiązaną nieważnie.

Niewątpliwie wyrok c. Burke należy uznać za zasługujący na uwage wkład ponensa w utrwalanie przez judykaturę rotalną właściwego rozumienia incapacitas assumendi, to jest zgodnie z tym, co Ustawodawca kościelny „odczytal” $w$ przestrzeni prawa naturalnego.

Incompatibilitas characterum et incapacitas assumendi (can. 1095, n. 3) in sententia Rotae Romanae c. Burke diei 18 iulii 1997

Summarium

In causa Singaporen. nullitatis matrimonii agitur de matrimonio celebato die 31 decembris 1983 in ecclesia Singaporensi a Simone et Adelina, quorum convictus coniugalis mox infelix devenit ob diversitatem indolis inter coniuges. Die 29 septembris 1985 vir matrimonium suum penes Tribunal Ecclesiasticum Singaporense accusavit nullitate. Die 16 februarii 1987 Tribunal sententiam affirmativam tulit ob radicalem incompatibilitatem charactrum coniugum. Appellata 
ad Tribunal Rotae Romanae sententia, die 5 martii 1991 rotalis turnus c. Colagiovanni causam examinavit et senteniam negativam edixit. Recurrente actore ad turnum sequentem (c. Burke), die 18 iulii 1997 sententia rotalis turni praecedentis confirmata est.

Illam sententiam rotalem c. Burke, in qua clare distinctio inter incompatibilitatem characterum et incapacitatem assumendi essentiales matrimonii obligationes explicitur (diversitas indolis viri et mulieris non aufert capacitatem tradendi et accipiendi iura et officia coniugalia), auctor presentat et commentat. 
Naktadem

Wydawnictwa Uniwersytetu Kardynała Stefana Wyszyńskiego

w Warszawie

ukazala się pozycja

\section{Marek Maciejczak}

\section{ŚWIADOMOŚĆ I SENS}

W filozofii współczesnej coraz większe zainteresowanie badaczy

budzi problematyka umysłu i świadomości jako jego aspektu.

Szansą sformułowania bardziej adekwatnej teorii świadomości stanowi, proponowana w niniejszej pracy interpretacja husserlowskiej teorii świadomości jako systemu intencjonalnych funkcji. Na tom składają się przejrzane i poprawione artykuły powstałe w latach 1993-2007. Jego charakter wyznacza czterech myślicieli:

I. Kant, F. Brentano, E. Husserl, M. Merleau-Ponty.

Dystrybucje prowadzi:

Wydawnictwo Uniwersytetu Kardynała Stefana Wyszyńskiego

01-815 Warszawa, ul. Dewajtis 5, tel. (0-22) 561-89-23; fax (0-22) 561-89-11

e.mail:wydawnictwo@uksw.edu.pl

www.wydawnictwo.uksw.edu.pl

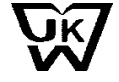

